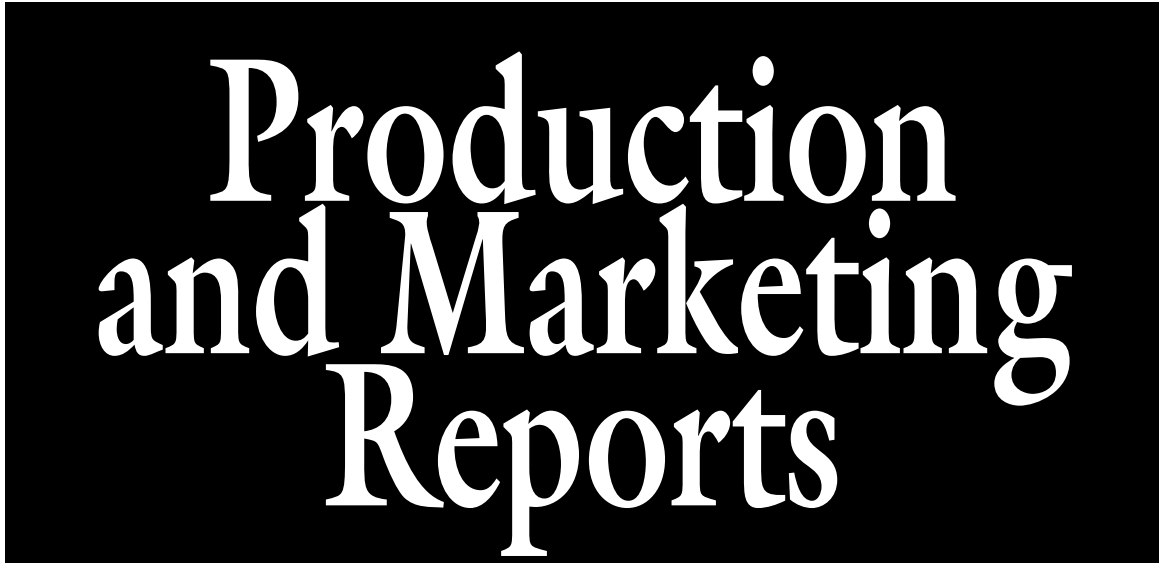

\section{Business and Marketing Practices of U.S. Landscape Firms}

\author{
Ariana Torres ${ }^{1,4,7}$, Susan S. Barton ${ }^{2,5}$, and Bridget K. Behe $e^{3,6}$
}

AdDITIONAL INDEX WORDs. customer, demographics, social media, survey

SUMMARY. Little information has been published on the business and marketing practices of landscape firms, an important sector of the green industry. We sought to profile the product mix, advertising, marketing, and other business practices of United States landscape firms and compare them by business type (landscape only, landscape/retail, and landscape/retail/grower) as well as by firm size. We sent the 2014 Trade Flows and Marketing survey to a wide selection of green industry businesses across the country and for the first time included landscape businesses. Herbaceous perennials, shade trees, deciduous shrubs, and flowering bedding plants together accounted for half of all landscape sales; $3 / 4$ of all products were sold in containers. However, landscape only firms sold a higher percentage of deciduous shrubs compared with landscape/retail/grower firms. Landscape businesses diversified their sales methods as they diversified their businesses to include production and retail functions. Landscape businesses spent, on average, $5.6 \%$ of sales on advertising, yet large landscape companies spent two to three times the percentage of sales on advertising compared with small- and medium-sized firms. Advertising as a percent of sales was three to four times higher for landscape/retail/ grower compared with landscape only or landscape/retail firms; most respondents used Internet advertising as their primary method of advertising. The top three factors influencing price establishment in landscape businesses were plant grade, market demand, and uniqueness of plants, whereas inflation was ranked as the least important of the nine factors provided. A higher percentage of small and mediumsized firms perceived last year's prices as more important in price establishment compared with large firms. A high percentage of large landscape companies said the ability to hire competent hourly employees was an important factor in business growth and management, but this was true only for about half of the small and medium-sized landscape companies.

$\mathrm{T}$ The United States environmental horticulture industry, or green industry, comprises wholesale nursery, greenhouse, and turfgrass sod producers; landscape design, installation and maintenance firms; as well as wholesale and retail distribution firms such as garden centers, home stores, mass merchandisers with lawn/garden departments, brokers and re-wholesale distribution centers, and allied trades suppliers of inputs to the industry. Firms that provide landscape services are not well documented in the literature. One of the few peer-reviewed publications about any landscape marketing or business practices was published 25 years ago from a survey of 62 Georgia landscape architects (Garber and Bondari, 1992a, 1992b, 1992c). Florkowski and Landry (2000) found labor to be the major expense of landscape firms. Haynes et al. (2007) more recently included the landscape sector in an industry survey of business practices in Iowa. They found that within the service sector, landscape installation and general landscape maintenance were the primary services offered. They also found the ability to hire qualified personnel was the most limiting factor for the service sector (Haynes et al., 2007). In the Lawn and Landscape 2016 State of the Industry report, finding quality labor was the biggest concern of respondents $(45 \%)$. Information about business practices, product mix, challenges facing business growth and management, establishment of prices, sales methods, and advertising is rare for this important sector of the green industry. Landscaping and horticultural services is the largest individual industry sector in terms of employment and gross domestic product contributions $[1,105,526$ jobs, $\$ 54.70$ billion (Hodges et al., $2015 b$ )]. As businesses become increasingly dependent on technology for marketing, it is important to understand how the landscape industry uses technology, specifically the Internet, effectively.

Since the 2008 Trade Flows and Marketing Practices survey (Hodges et al., 2010), technology use by businesses has increased (Charness and Boot, 2009; Dukes, 2014). More people use technology in their daily lives, and therefore, technology-based marketing has become a more viable avenue for businesses to reach consumers. Current research shows that $81 \%$ of American adults use the Internet; over half of them are using two or more social media sites (Duggan et al., 2015). Technology from an advertising and promotion standpoint can include webpages, online newsletters, e-mail messages, text messages, blogs, quick response codes on products, and a wide variety of social media. In the Paid Social Media Report, social networks and blogs are the top online destinations, accounting for most of the time spent online by U.S. active Internet users and reaching $80 \%$ or more of those users (Nielsen, 2013). In this article, we look at the use of the Internet in sales generation and advertising by landscape firms.

Given the importance of landscapers in the green industry and with little research documenting their business practices, we sent the 2014 Trade Flows and Marketing Practices survey to a wider variety of firms in the green industry to include data from landscape firms who provided a variety of functions (e.g., landscape services, 
retail sales, and plant production) (Hodges et al., 2015b). A wide variety of green industry businesses answered questions about product type, product form, sales method, advertising, factors determining prices, and factors impacting business growth and management. The objective of this article is to describe the marketing and business practices of landscape service providers gleaned from that survey.

\section{Materials and methods}

The 2014 Trade Flows and Marketing survey gathered information on business practices for calendar year 2013 or fiscal year 2013-14. The University of Florida Institutional Review Board for compliance with ethical standards for human subjects research approved the questionnaire and survey protocol.

This study represented the sixth national survey conducted by the Green Industry Research Consortium, following previous surveys in 1989, 1994, 1999, 2004, and 2009 (Brooker and Turner, 1990; Brooker et al., 2000, 2005; Hodges et al., 2010). The 2014 survey (Hodges et al., 2015a) targeted plant dealer firms with new questions regarding retail marketing practices. For the 2014 survey, we developed a list of over 110,000 grower and plant dealer firms in the United States. The list contained information on company name, contact person, mailing address, and in some cases telephone numbers, e-mail addresses, and type of business (grower or dealer). We obtained the listings for each state from members of the

\footnotetext{
We thank the Horticultural Research Institute, who supplied funding which was essential for data collection. We also thank the members of the S- 1065 Regional Project for the data, especially Dr. Alan Hodges, University of Florida, who led the survey data collection and dataset verification efforts.

Researcher salary for this project was supported by the USDA National Institute of Food and Agriculture, Hatch Project Number MICL 02085 and by Michigan State University AgBioResearch.

${ }^{1}$ Department of Horticulture \& Landscape Architecture and Agricultural Economics, Purdue University, 625 Agriculture Mall Drive, West Lafayette, IN 47907

${ }^{2}$ Department of Plant \& Soil Sciences, University of Delaware, 146 Townsend Hall, Newark, DE 19716

${ }^{3}$ Department of Horticulture, Michigan State University, 1066 Bogue Street, East Lansing, MI 48824

${ }^{4}$ Assistant Professor

${ }^{5}$ Professor and Extension Specialist

${ }^{6}$ Professor
}

${ }^{7}$ Corresponding author. E-mail: torres2@purdue.edu. doi: 10.21273/HORTTECH03835-17
National Plant Health Board, an organization representing the plant health regulatory agencies in each state, which in most cases is the state department of agriculture or its equivalent. All commercial growers and dealers of live plants are required to be registered and annually certified for compliance with phytosanitary regulations, so these lists of plant growers and dealers can be considered exhaustive to the extent legal compliance. Some states list these firms on a website, whereas others provided us with their list upon request. We obtained usable lists of certified nurseries and plant dealers from all states except Alaska, Montana, and New Mexico; for these states, lists of firms were obtained from the InfoSource USA database. After screening to eliminate duplicate entries and firms no longer in business, the effective population had over 104,000 firms. We targeted a total of 32,000 firms for the survey, including 15,000 grower or grower/dealer firms randomly selected to receive the questionnaire mailed by the U.S. Postal Service, and all 17,000 firms with e-mail addresses who received the survey by e-mail (Internet). We removed firms to be surveyed through e-mail from the population considered for the mail survey to avoid duplication.

We distributed the Trade Flows and Marketing survey during July through Aug. 2014. A summary of general findings from the study can be found in Hodges et al. (2015a). We implemented the online version of the survey at the same time as the mail survey and followed the same general approach for best practices in survey research, which includes an introductory letter, two mailed surveys, and postcards sent to non-respondents (Dillman et al., 2000). We used SurveyMonkey® web software (Palo Alto, CA) to send batch e-mail invitations, record survey responses in security-encrypted form, and track respondents. We sent three invitations to participate in the survey in July and Aug. 2014, with the second and third e-mail invitations sent only to previously non-responsive firms. We invited firms to participate in the online survey by clicking a link in the e-mail message directing them to the survey website. We explicitly asked respondents for consent to participate in the survey, and gave them the option to decline or "opt-out", as required by laws governing electronic communications. We asked consenting respondents a qualifying question: "Was your company actively involved in producing and marketing ornamental plants last year (2013)?"We directed respondents answering this question affirmatively to proceed with the survey, whereas those answering negatively were thanked and the survey was ended.

A question on the "advertising media used as a percentage of advertising expenses" asked respondents to choose from the following possible responses: Internet, Yellow Pages, radio/ television, billboards, gardening publications, catalogs (print or CD), trade journals, newsletters, trade shows, social media, or other. The "other" category included a field for writing in the type of "other" media used. Newspaper was not included in the list of potential responses, so newspaper responses reported in this study are a result of respondents' write-in responses. This may have resulted in skewed results for newspaper responses.

For the purposes of this report, we analyzed respondents who categorized themselves as landscapers with $>\$ 10,000$ in yearly sales, representing businesses generating sales that could potentially provide more than a second income. We divided respondents into categories by business type (i.e., business functions performed) and by size (i.e., sales). The type categories included businesses who identified themselves as landscaper only (LO), landscape and retail (LR), and landscape, retail, and grower (LRG). For size comparisons, we classified firms into three groups based on 2013 gross sales dollar volume: large firms had sales $\geq \$ 750,000$; medium firms had $\$ 125,000$ to $\$ 749,999$ in sales; and small firms had $\$ 10,000$ to $\$ 124,999$ in sales.

We conducted all analyses using Stata (release 14; StataCorp, College Station, TX). We made multiple comparisons among means in the analysis of variance (ANOVA) models using Tukey's honestly significant difference method at the $10 \%$ significance level. We considered business type and business size treatment effects for means comparisons across columns. We also compared means across rows by defining factors (i.e., product mix, advertising, marketing, and factors affecting prices and business growth) as the treatment effect and grouping businesses into three blocks according to the size 
(i.e., small, medium, and large) or type of business (i.e., LO, LR, and LGR). We also performed chi-square tests to measure the relationship between means, which yielded similar outcomes than ANOVA and Tukey's significance tests.

\section{Results}

A total of 32,000 firms were contacted for the survey by both mail and e-mail (Internet) methods. Valid responses were received from 2657 firms, including $1712(64 \%)$ from the mail survey and $945(36 \%)$ from the e-mail survey. A total of 299 (2.0\%) of mailed surveys were returned as undeliverable, and 958 (5.6\%) e-mail addresses were considered undeliverable. In addition, 377 firms refused to participate ("opted-out") of the e-mail survey. After deducting the undeliverable and non-compliant firms, the overall response rate for the survey was $\sim \approx 8 \%$.

After removing a number of very small firms claiming $<\$ 10,000$ in yearly sales that were clearly not participating in the business full-time, there were 120 useful responses; 59 businesses identified themselves as LO, 39 respondents listed LR, and 22 respondents listed LRG. For firm size comparisons, there were 34 large firms; 63 medium firms; and 23 small firms (Table 1 ). Of the 120 responses, most businesses were located in Indiana (27), Florida (22), Washington (13), Wisconsin (12), and Georgia (11). Fewer firms were located in Nebraska (7), Oregon (7), South Carolina (5), Kentucky (4), Tennessee (4), New York (3), Mississippi (1), Oklahoma (1), Rhode Island (1), Utah (1), and Vermont (1). Similar trends were observed when looking at business categories and sizes.

COMPARISONS BY BUSINESS TYPE. Product mix, or what the company sells, is an important business attribute. Herbaceous perennial plants

Table 1. Number of respondents to the 2014 Trade Flows and Marketing survey categorized by business type and firm size [small (\$10,000 to $\$ 124,999$ sales), medium (\$125,000 to $\$ 749,999$ sales), large $(\geq \$ 750,000$ sales $)$ ].

\begin{tabular}{lccrr}
\hline Firm size & $\begin{array}{c}\text { Full sample: } \\
\text { Responses [no. (\%)] }\end{array}$ & $\begin{array}{c}\text { Landscape only: } \\
\text { Responses [no. (\%)] }\end{array}$ & $\begin{array}{c}\text { Landscape and retailer: } \\
\text { Responses [no. (\%)] }\end{array}$ & $\begin{array}{c}\text { Landscape, retailer, and grower: } \\
\text { Responses [no. (\%)] }\end{array}$ \\
\hline Large & $34(28 \%)$ & $12(21 \%)$ & $13(39 \%)$ & $9(41 \%)$ \\
Medium & $63(53 \%)$ & $35(59 \%)$ & $19(49 \%)$ & $9(41 \%)$ \\
Small & $23(19 \%)$ & $12(20 \%)$ & $7(18 \%)$ & $4(18 \%)$ \\
Total & 120 & 59 & 39 & 22 \\
\hline
\end{tabular}

Table 2. Comparison of percent of type of product sold for 120 landscape firms by business type [full sample $(N=120)$; landscape only $(N=59)$; landscape and retailer $(N=39)$; landscape, retail, and grower $(N=22)]$ from the 2014 Trade Flows and Marketing survey.

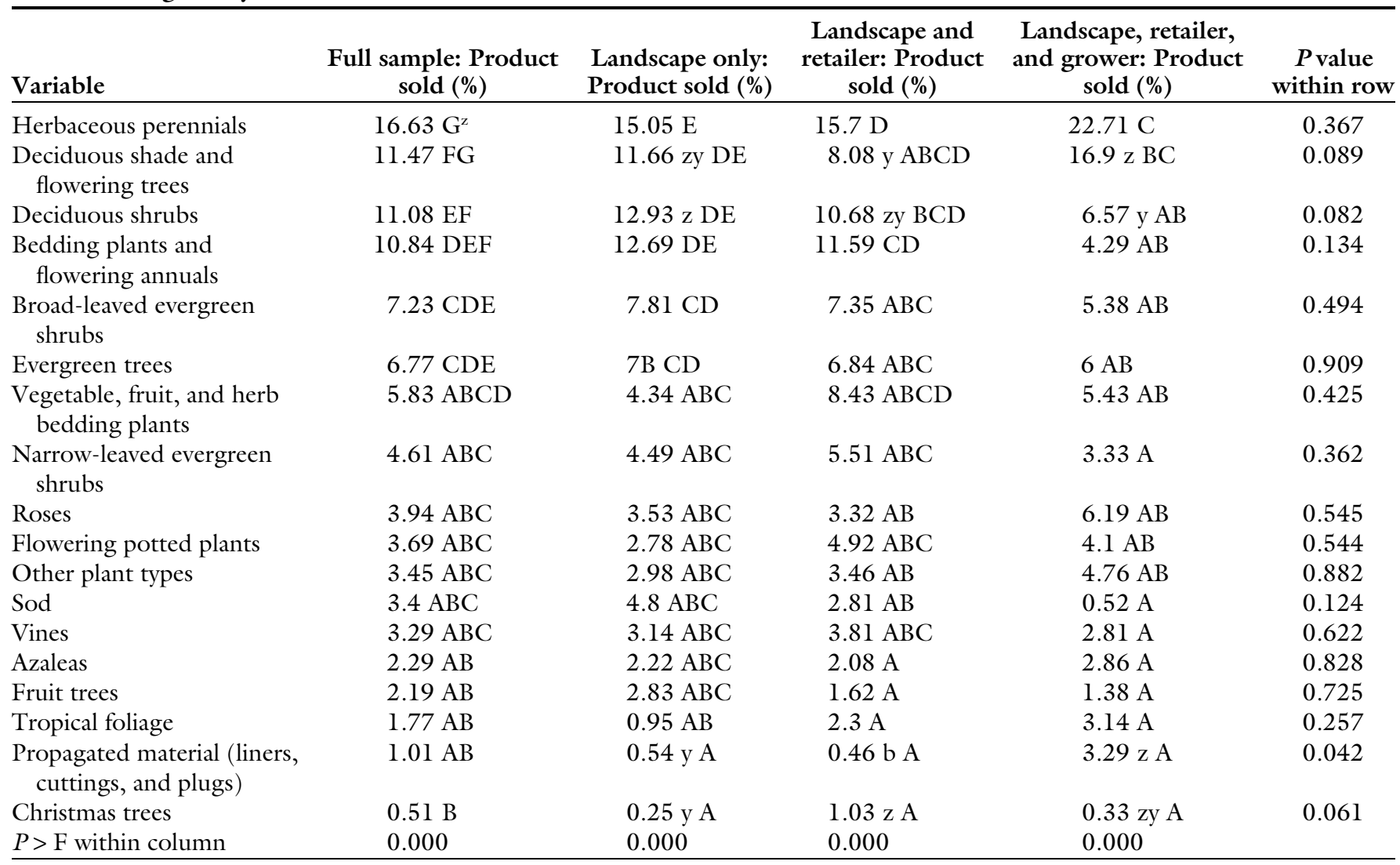

${ }^{\mathrm{z}}$ Upper case letters show statistically significant differences within column. Lower case letters show statistically significant differences across the row at $P<0$. 10 using Tukey's significant difference test. 
(16.6\%) comprised the highest percentage of sales across all firm types, followed by shade trees (11.5\%), deciduous shrubs (11.1\%), and flowering bedding plants $(10.8 \%)$. These were, generally, the most important products sold by all types of landscape companies. The least important products accounted for generally $\leq 5 \%$ of sales. When we compared the product mix by type of landscape business, we found several differences (Table 2). LRG firms sold more than twice the percentage of deciduous shade trees compared with LR; LO had a percentage of deciduous shade trees intermediate to that $(P=0.089)$. However, LO sold a higher percentage of deciduous shrubs compared with LRG with LR having a percentage similar to $\operatorname{LR}(P=0.082)$. LR sold a higher percentage of Christmas trees compared with LO, and LRG had a percentage intermediate to them $(P=$ 0.061 ). LRG sold $3.3 \%$ of propagation material, whereas LO and LR sold about $0.5 \%$ of propagation material $(P=0.042)$.

We compared the percent of sales by product form for the three types of landscape companies and found no differences (Fig. 1). Three-fourths of all products were sold in containers and $16.1 \%$ were sold as balled-and-burlapped. These two forms accounted for most of the sales $(90 \%)$. All other product forms (potin-pot, bare root, field grown, and ball-in-pot) generally accounted for by $4 \%$ or less of sales and was similar across firm types.

In comparing how landscape firms generated sales, all LO businesses generated $100 \%$ of their sales in person (Fig. 2). We found that landscape businesses diversified their sales methods as they diversified their business functions (i.e., growing and retailing). For example, LR generated nearly $12 \%$ of their sales over the telephone, which was similar to the LRG, which generated $17 \%$ of their sales over the telephone. Mail, trade shows, and Internet generated less than $8 \%$ of sales each for all types of landscape businesses. In comparing new sales vs. repeat sales, more than $60 \%$ of all sales came from repeat business $[\mathrm{LO}=66.4 \%, \mathrm{LR}=64.8 \%, \mathrm{LRG}=$ $66.7 \%(P=0.949)]$.

Advertising expenditures as a percent of sales was highest for LRG (12.4\%), which was three or four times higher than for LO $(3.8 \%)$ and LR $(4.5 \%)$, respectively $(P=0.018)$. Most respondents (32.5\%) listed Internet advertising as their primary method of advertising (Table 3). Because the survey failed to include newspaper and direct mail as categories within the methods of advertising list, there were a significant number of "other" responses $(N=$ 57 ). Of those, $26 \%$ reported advertising in newspapers and $24.6 \%$ listed direct mail. Yellow Pages was listed by $11.2 \%$ of respondents. Social media advertising was listed by $9.3 \%$ of respondents. Radio and television advertising was listed by $5.8 \%$ of overall respondents and newsletters was listed by $6.1 \%$ of overall respondents. Combining Internet with social media, electronic media accounted for nearly half of all landscape business advertising. Trade shows, catalogs, bills, journals, and publications accounted for generally less than 5\% of advertising methods each. When we compared advertising forms by business type, we found one difference (Table 3). Radio and television advertising was ten times the magnitude for LRG and LR compared with LO $(P=0.057)$.

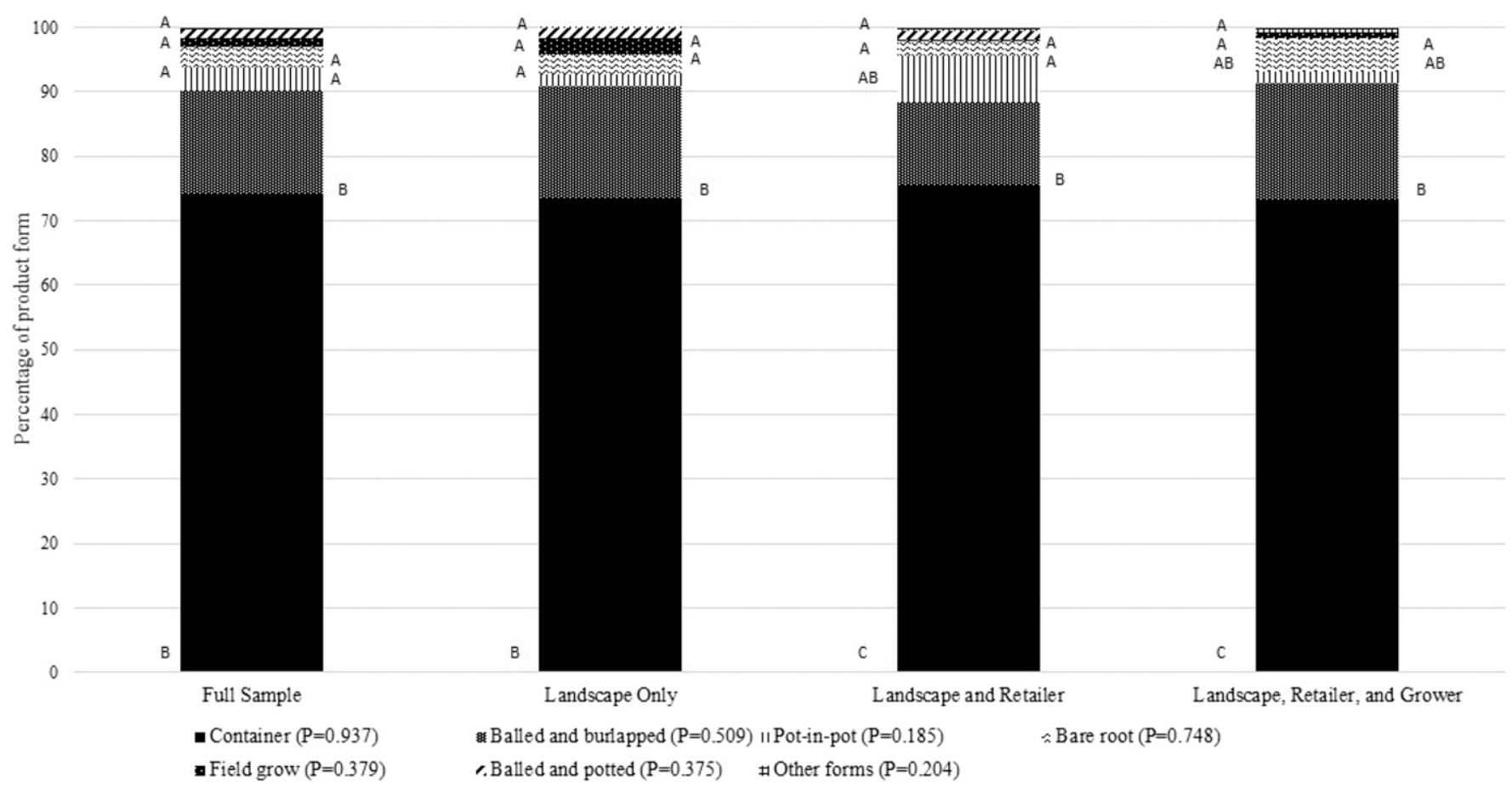

Fig. 1. Comparison of percent of product form sold for 120 landscape firms by business type [full sample $(N=120)$; landscape only $(N=59)$; landscape and retailer $(N=39)$; landscape, retail, and grower $(N=22)]$ from the 2014 Trade Flows and Marketing survey. Upper case letters show statistically significant differences within column; lower case letters show statistically significant differences across the row at $P<0.10$ using Tukey's significant difference test. 


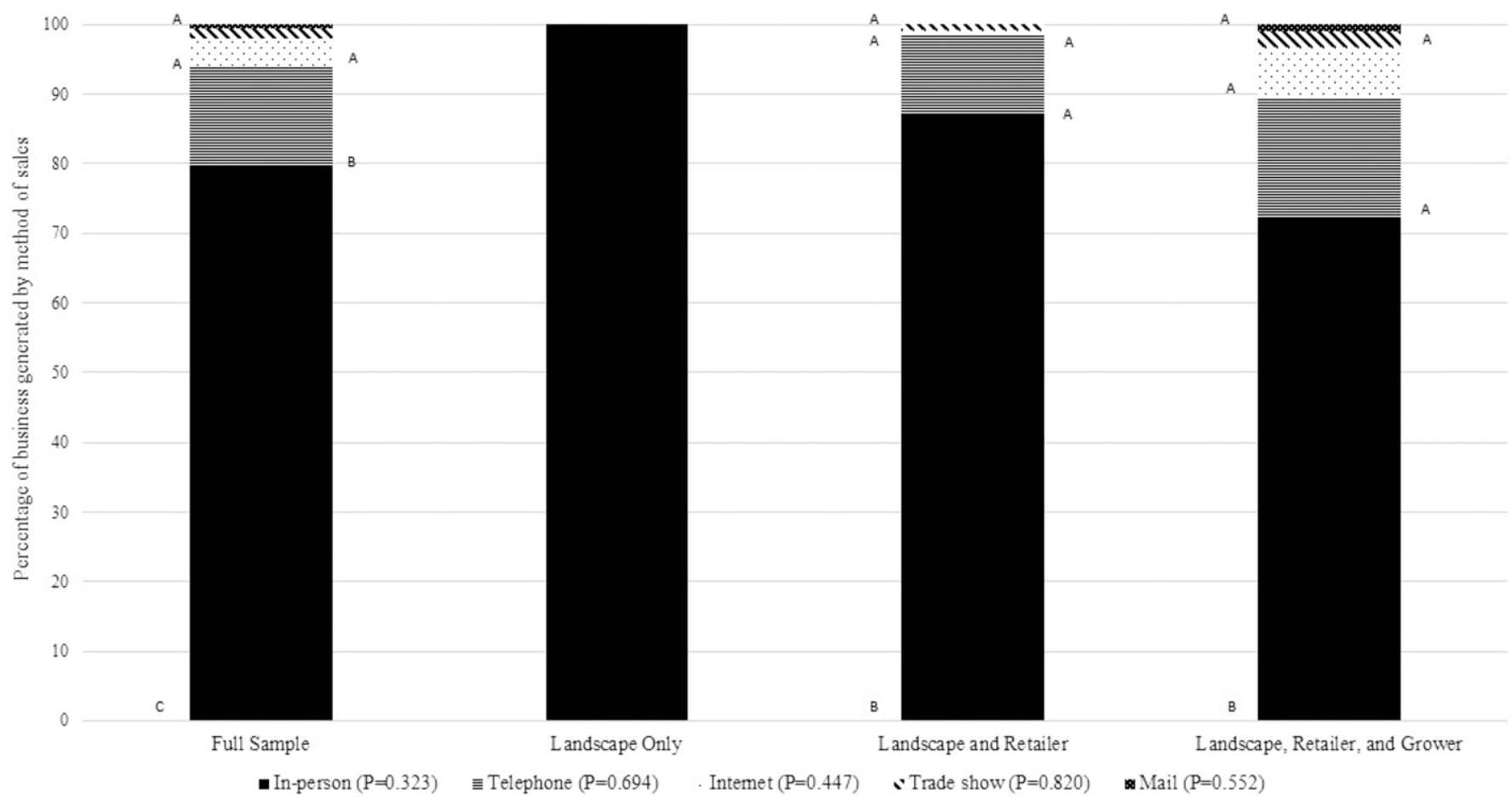

Fig. 2. Comparison of percent of business generated by method of sales for 120 landscape firms by business [full sample $(N=$ 120); landscape only $(N=59)$; landscape and retailer $(N=39)$; landscape, retail, and grower $(N=22)]$ from the 2014 Trade Flows and Marketing survey. Upper case letters show statistically significant differences within column; lower case letters show statistically significant differences across the row at $P<0.10$ using Tukey's significant difference test.

Table 3. Comparison of percent of advertising spent on 11 types of advertising for 120 landscape firms by business type [full sample $(N=120)$; landscape only $(N=59)$; landscape and retailer $(N=39)$; landscape, retail, and grower $(N=22)]$ from the 2014 Trade Flows and Marketing survey.

\begin{tabular}{|c|c|c|c|c|c|}
\hline Variable & $\begin{array}{c}\text { Full sample: } \\
\text { Advertising } \\
\text { spent }(\%)\end{array}$ & $\begin{array}{c}\text { Landscape only: } \\
\text { Advertising spent (\%) }\end{array}$ & $\begin{array}{l}\text { Landscape and retailer: } \\
\text { Advertising spent (\%) }\end{array}$ & $\begin{array}{c}\text { Landscape, retailer, } \\
\text { and grower: advertising } \\
\text { spent (\%) }\end{array}$ & $\begin{array}{c}P \text { value } \\
\text { within row }\end{array}$ \\
\hline Internet & $32.49 \mathrm{D}^{\mathrm{z}}$ & $33.59 \mathrm{~B}$ & $27.78 \mathrm{C}$ & $38.39 \mathrm{C}$ & 0.571 \\
\hline Yellow Pages & $11.24 \mathrm{C}$ & $11.71 \mathrm{~A}$ & $11.66 \mathrm{AB}$ & $9.44 \mathrm{AB}$ & 0.939 \\
\hline Social media & $9.29 \mathrm{BC}$ & $10.61 \mathrm{~A}$ & $10.78 \mathrm{AB}$ & $3.61 \mathrm{~A}$ & 0.421 \\
\hline Newsletter & $6.07 \mathrm{ABC}$ & $2.22 \mathrm{y} \mathrm{A}$ & $12.53 \mathrm{z} \mathrm{AB}$ & 3.33 y A & 0.190 \\
\hline Trade show & $3.05 \mathrm{AB}$ & $2.20 \mathrm{~A}$ & $4.78 \mathrm{AB}$ & $1.94 \mathrm{~A}$ & 0.675 \\
\hline Catalog (print/CD) & $2.80 \mathrm{AB}$ & $1.71 \mathrm{~A}$ & $2.19 \mathrm{~A}$ & $6.39 \mathrm{AB}$ & 0.338 \\
\hline Billboard & $1.55 \mathrm{AB}$ & $2.95 \mathrm{~A}$ & $0.63 \mathrm{~A}$ & $0.00 \mathrm{~A}$ & 0.298 \\
\hline Trade journal & $0.27 \mathrm{~A}$ & $0.61 \mathrm{~A}$ & $0.00 \mathrm{~A}$ & $0.00 \mathrm{~A}$ & 0.549 \\
\hline Gardening publications & $0.23 \mathrm{~A}$ & $0.02 \mathrm{~A}$ & $0.34 \mathrm{~A}$ & $0.50 \mathrm{~A}$ & 0.328 \\
\hline$P>\mathrm{F}$ within column & 0.000 & 0.000 & 0.000 & 0.000 & \\
\hline
\end{tabular}

${ }^{\mathrm{z}}$ Upper case letters show statistically significant differences within column. Lower case letters show statistically significant differences across the row at $P<0.10$ using Tukey's significant difference test.

We asked each firm to rate the importance of nine factors that may impact price setting using a scale from 1 (not at all important) to 4 (very important) in their pricing decision, and we calculated the percentage of firms who responded 3 (important) or 4 (very important) (Table 4 ). The top three factors influencing price setting in landscape businesses were plant grade $(94 \%)$, market demand
$(81 \%)$, and uniqueness of plants $(80 \%)$. Inflation was the least important of the factors and ranked eighth or ninth for all of the firms. When comparing the price setting factors across business types we found two differences. About 20\% more LRs indicated that product uniqueness was important compared with LO, but similar to LRG $(P=0.084)$. The factor that had the highest percentage of LRs responding was plant grade (94.6\%). A higher percentage of LRG $(95.5 \%)$ responded that production costs were an important factor to determine prices compared with LO $(70.2 \%)$ and $\operatorname{LR}(75.7 \%)(P=0.062)$.

We also asked companies to indicate how important 13 items were to the growth and management of the business. We asked them to respond using the same 1 to 4 scale as for price 
Table 4. Percentage of 120 landscape businesses indicating each of nine factors as (3) important or (4) very important in affecting the establishment of prices by business type [full sample $(N=120)$; landscape only $(N=59)$; landscape and retailer $(N=39)$; landscape, retail, and grower $(N=22)$ ] from the 2014 Trade Flows and Marketing survey.

\begin{tabular}{|c|c|c|c|c|c|}
\hline Variable & $\begin{array}{l}\text { Full sample: } \\
\text { Responses (\%) }\end{array}$ & $\begin{array}{l}\text { Landscape only: } \\
\text { Responses (\%) }\end{array}$ & $\begin{array}{c}\text { Landscape and retailer: } \\
\text { Responses }(\%)\end{array}$ & $\begin{array}{l}\text { Landscape, retailer, and } \\
\text { grower: Responses (\%) }\end{array}$ & $\begin{array}{l}P \text { value within } \\
\text { row }\end{array}$ \\
\hline Plant grade & $93.69 \mathrm{D}^{\mathrm{z}}$ & $94.23 \mathrm{~B}$ & $94.59 \mathrm{C}$ & $90.91 \mathrm{CD}$ & 0.837 \\
\hline Market demand & $81.31 \mathrm{CD}$ & $77.55 \mathrm{AB}$ & $83.33 \mathrm{C}$ & $86.36 \mathrm{CD}$ & 0.636 \\
\hline Product uniqueness & $80.18 \mathrm{CD}$ & $73.08 \mathrm{z} \mathrm{AB}$ & 91.89 z C & $77.27 \mathrm{yz}$ BCD & 0.084 \\
\hline Cost of production & $77.36 \mathrm{CD}$ & 70.21 y $\mathrm{AB}$ & 75.68 yz BC & $95.45 \mathrm{z} \mathrm{D}$ & 0.062 \\
\hline Other growers prices & $66.67 \mathrm{BC}$ & $65.91 \mathrm{~A}$ & $69.44 \mathrm{ABC}$ & $63.64 \mathrm{BCD}$ & 0.895 \\
\hline Inflation & $45.00 \mathrm{~A}$ & $52.38 \mathrm{~A}$ & $47.22 \mathrm{~A}$ & $27.27 \mathrm{~A}$ & 0.153 \\
\hline Other growers prices & $35.00 \mathrm{AB}$ & $36.36 \mathrm{~A}$ & $50.00 \mathrm{ABC}$ & $0.00 \mathrm{~A}$ & 0.368 \\
\hline$P>\mathrm{F}$ within column & 0.000 & 0.000 & 0.000 & 0.000 & \\
\hline
\end{tabular}

${ }^{\mathrm{z}}$ Upper case letters show statistically significant differences within column. Lower case letters show statistically significant differences across the row at $P<0.10$ using Tukey's significant difference test.

Table 5. Percentage of 120 landscape firms saying each of 13 factors were important (3) or very important (4) factors affecting business growth and development by business type [full sample $(N=120)$; landscape only $(N=59)$; landscape and retailer $(N=39)$; landscape, retail, and grower $(N=22)$ ] from the 2014 Trade Flows and Marketing survey.

\begin{tabular}{|c|c|c|c|c|c|}
\hline$\underline{\text { Variable }}$ & $\begin{array}{c}\text { Full sample: } \\
\text { Responses (\%) }\end{array}$ & $\begin{array}{l}\text { Landscape only: } \\
\text { Responses (\%) }\end{array}$ & $\begin{array}{l}\text { Landscape and } \\
\text { retailer: } \\
\text { Responses (\%) }\end{array}$ & $\begin{array}{c}\text { Landscape, retailer, } \\
\text { and grower: } \\
\text { Responses }(\%)\end{array}$ & $\begin{array}{c}P \text { value } \\
\text { within row }\end{array}$ \\
\hline Market demand & $88.39 \mathrm{D}^{\mathrm{z}}$ & $83.33 \mathrm{~F}$ & $88.89 \mathrm{~F}$ & $100 \mathrm{D}$ & 0.122 \\
\hline Own managerial expertise & $79.63 \mathrm{CD}$ & $75.47 \mathrm{EF}$ & $85.29 \mathrm{EF}$ & $80.95 \mathrm{BCD}$ & 0.540 \\
\hline Weather uncertainty & $76.79 \mathrm{CD}$ & $69.09 \mathrm{DEF}$ & $80 \mathrm{DEF}$ & $90.91 \mathrm{CD}$ & 0.108 \\
\hline Labor & $75.22 \mathrm{CD}$ & $74.55 \mathrm{DEF}$ & 80.56 DEF & $68.18 \mathrm{ABCD}$ & 0.570 \\
\hline Competition/price undercutting & $58.04 \mathrm{AB}$ & $50 \mathrm{ABCD}$ & 69.44 ABCD & $59.09 \mathrm{ABC}$ & 0.191 \\
\hline Other government regulations & $55.56 \mathrm{AB}$ & $58.49 \mathrm{BCDE}$ & $50 \mathrm{BCDE}$ & $57.14 \mathrm{ABC}$ & 0.735 \\
\hline Environmental regulations & $53.64 \mathrm{AB}$ & 61.11 BCDEF & 45.71 BCDEF & $47.62 \mathrm{AB}$ & 0.307 \\
\hline Water supply & $50.91 \mathrm{~A}$ & $50 \mathrm{ABCD}$ & $50 \mathrm{ABCD}$ & $54.55 \mathrm{ABC}$ & 0.932 \\
\hline $\begin{array}{l}\text { Ability to hire competent } \\
\text { management }\end{array}$ & $50.45 \mathrm{~A}$ & 53.57 ABCDE & $54.55 \mathrm{ABCDE}$ & $36.36 \mathrm{~A}$ & 0.341 \\
\hline$P>\mathrm{F}$ within column & 0.000 & 0.000 & 0.000 & 0.000 & \\
\hline
\end{tabular}

${ }^{\mathrm{z}}$ Upper case letters show statistically significant differences within column. Lower case letters show statistically significant differences across the row at $P<0.10$ using Tukey's significant difference test.

setting. Market demand, own managerial expertise, weather uncertainty, and labor (generally) were the most important factors affecting businesses (Table 5). We found two differences when comparing firm types. Land was important to $63.4 \%$ of LRG but to only $28.9 \%$ of $\mathrm{LO}(P=0.018)$. Fortyfour percent of LR indicated that land was an important factor for business growth. The ability to hire competent hourly labor was more important for $\operatorname{LR}(77.8 \%)$ and $\operatorname{LO}(65.5 \%)$ firms than for LRG firms $(50.0 \%)$ $(P=0.093)$.

Comparisons by bUSINESS SIZE. We compared the product mix of small, medium, and large companies and found five differences (Table 6). Large and medium firms had 1.5 to two times higher percentages of sales from evergreen trees than small firms $(P=0.069)$. Large and medium firms also sold nearly two times more broad-leaved evergreens compared with small firms $(P=0.089)$. Small firms sold three to four times higher percentage of flowering potted plants compared with medium and large firms $(P=0.028)$. Large firms had $6.8 \%$ of their sales from sod, whereas small and medium firms had about $2 \%$ of their sales from sod $(P=0.021)$. Propagation material accounted for $3.7 \%$ of the sales of small landscape companies, but only
$0.4 \%$ and $0.3 \%$ for medium and large firms, respectively $(P=0.007)$.

Plant material in containers accounted for most product sales of all sized firms, we found that medium firms sold over three-quarters of their plants in containers, whereas small firms sold two-thirds in containers $[P=0.062$ (Fig. 3)]. On average, small landscape companies sold nearly $12.3 \%$ of their product as pot-in-pot, whereas it comprised a much smaller percentage of sales for large firms $(3.5 \%)$ and medium firms $(0.5 \%)$ $(P=0.004)$.

Landscape businesses spent, on average, $5.6 \%$ of sales on advertising. Large landscape companies spent two 
Table 6. Comparison of 120 landscape firms on the percentage of plant types sold by business size [full sample $(N=120)$, small $(N=23)$, medium $(N=63)$, large $(N=34)$ ] from the 2014 Trade Flows and Marketing survey.

\begin{tabular}{|c|c|c|c|c|c|}
\hline Variable & $\begin{array}{l}\text { Full sample: Plant } \\
\text { types sold }(\%)\end{array}$ & $\begin{array}{l}\text { Small: Plant } \\
\text { types sold (\%) }\end{array}$ & $\begin{array}{l}\text { Medium: Plant } \\
\text { types sold (\%) }\end{array}$ & $\begin{array}{l}\text { Large: Plant } \\
\text { types sold (\%) }\end{array}$ & $\begin{array}{c}\text { P value } \\
\text { within row }\end{array}$ \\
\hline Herbaceous perennials & $16.63 \mathrm{G}^{\mathrm{z}}$ & $20.91 \mathrm{~B}$ & $17.23 \mathrm{D}$ & $12.79 \mathrm{D}$ & 0.379 \\
\hline Deciduous shade and flowering tree & $11.47 \mathrm{FG}$ & $11.91 \mathrm{AB}$ & $11.02 \mathrm{BCD}$ & $12.00 \mathrm{DEF}$ & 0.942 \\
\hline Deciduous shrubs & $11.08 \mathrm{EF}$ & $7.95 \mathrm{~A}$ & $11.15 \mathrm{BCD}$ & $12.97 \mathrm{D}$ & 0.268 \\
\hline Flowering annual bedding plant & 10.84 DEF & $5.23 \mathrm{~A}$ & $13.16 \mathrm{CD}$ & 10.29 DEF & 0.158 \\
\hline Broad-leaved evergreen shrubs & $7.23 \mathrm{CDE}$ & $4.45 \mathrm{y} \mathrm{A}$ & $7.1 \mathrm{zy} \mathrm{ABC}$ & $9.26 \mathrm{z}$ BCDEF & 0.089 \\
\hline Narrow-leaved evergreen shrubs & $4.61 \mathrm{ABC}$ & $4.82 \mathrm{~A}$ & $4.11 \mathrm{~A}$ & 5.35 ABCDEF & 0.584 \\
\hline Roses & $3.94 \mathrm{ABC}$ & $2 \mathrm{~A}$ & $5.49 \mathrm{AB}$ & $2.41 \mathrm{AB}$ & 0.234 \\
\hline Flowering potted plants & $3.69 \mathrm{ABC}$ & $8.41 \mathrm{z} \mathrm{AB}$ & 2.33 y A & 3.09 y ABC & 0.028 \\
\hline Other plant types & $3.45 \mathrm{ABC}$ & $8.23 \mathrm{AB}$ & $2.46 \mathrm{~A}$ & $2.15 \mathrm{~A}$ & 0.200 \\
\hline Sod & $3.40 \mathrm{ABC}$ & $1.68 \mathrm{y} \mathrm{A}$ & $2.15 \mathrm{y} \mathrm{A}$ & $6.76 \mathrm{z} \mathrm{ABCDEF}$ & 0.021 \\
\hline Vines & $3.29 \mathrm{ABC}$ & $2.68 \mathrm{~A}$ & $3.49 \mathrm{~A}$ & $3.32 \mathrm{ABC}$ & 0.733 \\
\hline Propagated materials (liners, cuttings, plugs) & $1.01 \mathrm{AB}$ & $3.73 \mathrm{z} \mathrm{A}$ & 0.43 y A & 0.29 y A & 0.007 \\
\hline Christmas trees & $0.51 \mathrm{~B}$ & $0.36 \mathrm{~A}$ & $0.49 \mathrm{~A}$ & $0.65 \mathrm{~A}$ & 0.807 \\
\hline$P>\mathrm{F}$ within column & 0.000 & 0.000 & 0.000 & 0.000 & \\
\hline
\end{tabular}

${ }^{\mathrm{z}}$ Upper case letters show statistically significant differences within column. Lower case letters show statistically significant differences across the row at $P<0.10$ using Tukey's significant difference test.

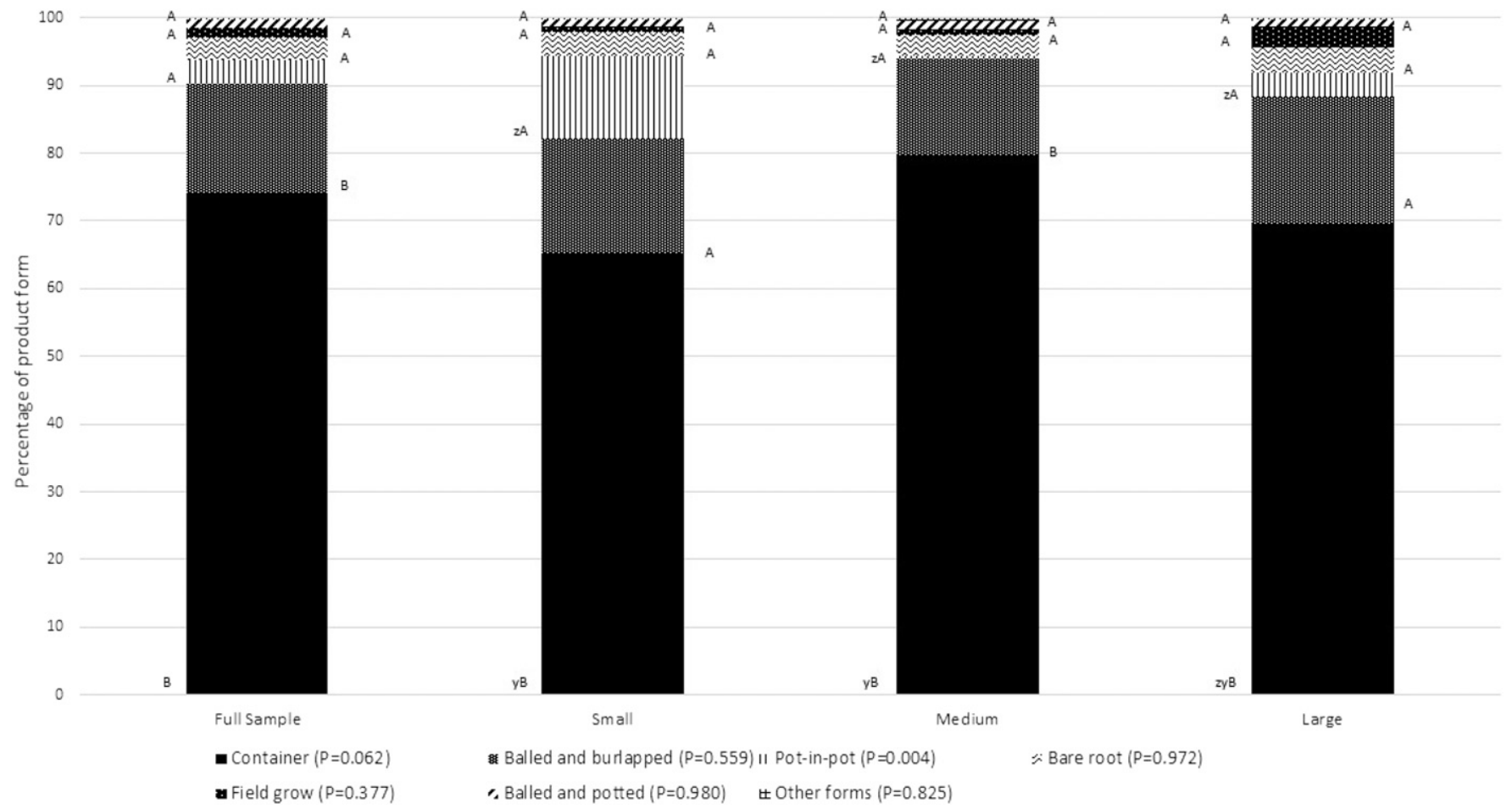

Fig. 3. Comparison of 120 landscape firms by business size [full sample $(N=120)$, small $(N=23)$, medium $(N=63)$, large $(N=34)$ ] on the percentage of product forms sold from the 2014 Trade Flows and Marketing survey. Upper case letters show statistically significant differences within column; lower case letters show statistically significant differences across the row at $P<0.10$ using Tukey's significant difference test.

to three times the percentage of sales on advertising that small and medium firms spent $(P=0.063)$. However, we found no differences in the percentage of advertising spent on different forms of advertising when comparing by business size.

We made comparisons by firm size for the percentage of businesses reporting that each of the nine factors influencing price setting was important and found only one difference. A higher percentage of medium $(64.2 \%)$ and small firms (57.9\%) perceived last year's prices were 
important in influencing price setting than large firms $(36.4 \%)(P=0.039)$.

We also made comparisons by firm size for the percentage of businesses reporting that each of 13 factors affecting the business was important, and found three differences. A high percentage $(84.9 \%)$ of large landscape companies said the ability to hire hourly employees was important for business growth and management, but this was true for only $50 \%$ of small and $62 \%$ of medium landscape companies $(P=0.016)$. Large firms were most concerned about labor $(85.3 \%)$ as compared with small firms (59.1\%), with medium firms intermediately concerned about labor $(75.4 \%) \quad(P=$ 0.083 ). Large and medium firms said weather uncertainty was an important factor affecting their business $(81.3 \%$ and $81.0 \%$, respectively), but only a little more than half the small firms $(59.1 \%)$ said weather uncertainty was important or very important $(P=0.091)$.

\section{Discussion}

Landscape firms exhibited several differences when they were compared by business type (LO, LR, and LRG). The product mix shifted slightly when retailer and/or grower functions were integrated into landscape firms. We observed an increase in the percentage of sales accounted for by deciduous shade and flowering trees when the grower function was a part of the business but a decrease when landscape businesses were also retailers or landscape only businesses. Landscape retailing businesses may elect to use their limited and valuable space for products that turnover faster or have a higher profit margin than deciduous shade and flowering trees. The decrease in the percentage of sales accounted for by deciduous shrubs when the grower function was added, especially compared with LO, may be due to the growers' decision to produce deciduous shade and flowering trees. Understandably, landscape firms with growing facilities may be best equipped to produce and market propagation material, thus accounting for six times the sales of propagated material when compared with LO and LR. With the retail function included in landscape companies, the sale of Christmas trees is much easier than for a LO firm; landscape service providers sell little that extends to the interior of the home.
We also observed changes in advertising expenditures when retailer or grower/retailer functions were added to the business (e.g., retail sales and plant production); television/radio became more important advertising mechanisms. The landscape service provider has traditionally relied on wordof-mouth communication rather than investing in formal advertising methods (Heiler, 2010). If the company is producing plants as well as retailing them (in addition to landscape services), they may use these more traditional communication/advertising measures (television/radio) to stay connected with their customer base and attract new customers. The number of potential consumer niches likely expands as the functions in the firm expand; thus, explaining why more vertically integrated businesses engaged in more diverse types of advertising. Diversification of functions may benefit from diversification of sales methods as we observed differences here as well.

In terms of factors affecting price establishment, plant grade was perceived as the most important factor for all types of businesses. When Campbell and Hall (2010) looked at price establishment for growers, they found cost of production and product inventory to be important factors. We found that plant grade was a more important attribute for LR than for LO businesses. We interpret plant grade as plant or container size. It is likely that plant size is more important for retailers as their customers view plants and make comparisons before purchase as opposed to LO firms, in which plants are delivered to a job site with no opportunity for consumers to compare size. We also found some differences in the importance of product uniqueness and cost of production. Landscapers are likely retained or hired for their expertise on delivering appealing services. In the retail arena, the product uniqueness probably "speaks to" or appeals to potential consumers before they verbally interact with any professional at the retail venue. By hiring the landscape service provider, the consumer is relinquishing the "control" of plant selection to the professional. By contrast, the consumer retains that "control" by selecting the LR or LGR, or unique plants. Perceptions of pricing also changed with the addition of retailer or grower/retailer functions to landscaping. Production costs became the greatest factor driving prices and uniqueness became less of a driver when a growing function was included in the firm. It is expected that more integrated and less specialized businesses tend to face more sophisticated cost structures (Sporleder, 1992), which likely will drive price determination.

As a growth and management concern, hourly or front-line labor was perceived as a less important factor when grower and retailer functions were integrated in the firm as compared with LO. Traditionally, labor has been a great challenge for the landscape service professional and others in the green industry (Haynes et al., 2007; Mathers et al., 2010). As a seasonal industry, the landscape-only firms may be challenged to retain employees yearround if they have no work for them in the off-season. We expect more diversified firms may have more year-round revenue generation opportunities than less diversified firms; thus, keeping labor busy and employed all year-round.

Landscape only businesses did not seem to perceive land as an important factor for business growth. The need of land by growers and retailers is crucial for production and retailing activities. Growers need more land for production and may favor greater land availability and lower prices. Retailers must have a visible location and would potentially pay a premium for land. Location may drive the success of a retailing operation, or pesticide/fertilizer applications may restrict growers to locate near residential neighborhoods. On the other hand, landscape firms are less likely to rely on land than LR or LGR firms as their activities take them to residential and commercial job sites. The location of the land also may affect the retailer more in comparison with the LO to attract customers.

Herbaceous perennials, deciduous shade and flowering trees, deciduous shrubs, and flowering annual bedding plants accounted for nearly half of all sales for all types of firms. Other products accounted for less than $10 \%$ of sales each. The product mix of landscape businesses was greatly affected by the size of business. Smaller firms sold a lower percentage of broad-leaved evergreen shrubs [excluding azaleas (Rhododendron sp.)], evergreen trees, and sod but a higher percentage of flowering potted plants compared with large firms. Larger landscape firms may 
have a larger percentage of commercial customers than smaller growers and may use more evergreen trees and broad-leaved evergreens in commercial sites in comparison with residential sites. We expect that visual properties of evergreens, such as year-round landscape performance, are key factors for larger firms to capture a higher share of commercial sites.

Container material clearly has become the production type to use, regardless of business size. Pot-in-pot production accounted for more than four times the percentage of sales in a small landscape firm compared with medium or large landscape firms. There were two of 38 firms in the small size growing exclusively as pot-in-pot, potentially skewing the results we found. In addition, one small-sized firm sold $65 \%$ of their sales as pot-in-pot; 58 of 63 medium sized firms sold no pot-inpot production. Because pot-in-pot production is not a well-accepted industry practice to date claiming less than $2 \%$ of market share (Hodges et al., 2015a), these few outliers likely skewed the findings.

Inperson sales were more important to small firms, whereas larger firms relied on more diverse sales approaches than in-person sales alone. Firm size did not affect the percentage of sales spent on advertising or advertising medium. In terms of price setting, last year's prices were much more important to smaller firms than to larger firms. Larger firms may have more decision-making processes (e.g., human resources, accounting, etc.) than small firms, which may enable them to focus more on more sophisticated financial measures to set prices, whereas smaller firms (with fewer complexities and resources) may rely more on last year's prices.

Landscape firms had slightly different business practices by both firm type (business functions they performed in addition to landscaping services) and by size of firm (annual revenues). The industry now has a baseline describing the business practices and the factors driving pricing and growth of this important sector of the green industry. In addition, it may serve as a benchmark for firms to use internally. One possible limitation of our study is the unintended exclusion of service or design firms that do not have an affiliation with the state department of agriculture, which prevented them of being included in our sample. Second, the small sample size of 120 firms may limit generalizability. Future research should document whether changes in the practices, especially advertising and the use of technology, occur in the coming years.

\section{Literature cited}

Brooker, J.R. and S.C. Turner. 1990. Trade flows and marketing practices within the United States nursery industry. Southern Coop. Ser. Bul. 358 for Southern Reg. Res. Project S-103. I Aug. 2017. <http:// aggie-horticulture.tamu.edu/faculty/ hall/publications/SCSB358.pdf>.

Brooker, J.R, R.A. Hinson, and S.C. Turner. 2000. Trade flows and marketing practices within the United States nursery industry: 1998. Southern Coop. Ser. Bul. 397 for Southern Reg. Res. Project S-290. 1 Aug. 2017. <http://aggie-horticulture.tamu. edu/faculty/hall/publications/SCB397. pdf $>$.

Brooker, J., D. Eastwood, C. Hall, K. Morris, A. Hodges, and J. Haydu. 2005. Trade flows and marketing practices within the United States nursery industry: 2003. Southern Coop. Ser. Bul. 404. 1 Aug. 2017. <http://aggie-horticulture.tamu.edu/ faculty/hall/publications/SCB404.pdfs.

Campbell, B.L. and C.R. Hall. 2010. Effects of pricing influences and selling characteristics on plant sales in the green industry. HortScience 45:575-582.

Charness, N. and W.R. Boot. 2009. Aging and information technology use. Curr. Dir. Psychol. Sci. 18:253-258.

Dillman, D.A. 2000. Mail and internet surveys: The tailored design method. Vol. 2. Wiley, New York, NY.

Duggan, M., N. Ellison, C. Lampe, A. Lenhart, and M. Madden. 2015. Social media update 2014. Pew Res. Ctr., Washington, DC.

Dukes, E. 2014. 4 Ways technology has changed the modern workplace. 3 Nov. 2016. <https://www.iofficecorp.com/ blog/4-ways-technology-has-changedthe-modern-workplace $>$.

Florkowski, W.J. and G. Landry. 2000. An economic profile of the professional turfgrass and landscape industry. Georgia Agr. Expt. Sta. Res. Rpt. No. 672. 29 Aug. 2017. <https://www.researchgate. net/profile/Wojciech_Florkowski/ publication/266454071_An_Economic_ Profile_of_the_Professional_Turfgrass_ and_Landscape_Industry_in/links / 54a6flf80cf267bdb90a0704.pdf>.

Garber, M.P. and K. Bondari. 1992a. Landscape architects as related to the landscape/ nursery industry: I. Impact on demand for plant material. J. Environ. Hort. 10:69-72.
Garber, M.P. and K. Bondari. 1992b. Landscape architects as related to the landscape/nursery industry: II. Selection of the production nursery and plant availability. J. Environ. Hort. 10:73-77.

Garber, M.P. and K. Bondari. 1992c. Landscape architects as related to the landscape/nursery industry: III. Sources of plant material information. J. Environ. Hort. 10:78-80.

Haynes, C., A.M. VanDerZanden, and J. K. Iles. 2007. A survey of the ornamental horticulture industry in Iowa. HortTechnology 17:513-517.

Heiler, C. 2010. The 10 rules of advertising: What every landscaping company should know about advertising. I Aug. 2017. <https://www.landscapeleadership. com/blog/bid/173965/the-10-rules-ofadvertising-what-every-landscaping-companyshould-know-about-advertising $>$.

Hodges, A.W., C.R. Hall, and M.A. Palma. 2010. Trade flows and marketing practices within the U.S. nursery industry, 2008. Southern Coop. Ser. Bul. 411, Multistate Reg. Res. Project S-1021. 1 Aug. 2017. <http://aggie-horticulture. tamu.edu/faculty/hall/publications / SCSB411.pdf>.

Hodges, A.W., C.R. Hall, M.A. Palma, and $\mathrm{H}$. Khachatryan. 2015b. Economic contributions of the green industry in the United States in 2013. HortTechnology 25:805-814.

Hodges, A.W., H. Khachatryan, C.R. Hall, and M.A. Palma. 2015a. Production and marketing practices and trade flows in the United States green industry, 2013. Southern Coop. Ser. Bul. 420. 1 Aug. 2017. <http://saaesd.ncsu.edu/docs/ National $\% 20$ Green $\% 20$ Industry $\%$ 20Survey $\% 2$ report $\% 202014 \% 20$ SCSB $\%$ 2052615.pdf>.

Lawn and Landscape. 2016. 2016 State of the industry report. 30 Aug. 2017. <http:// www.lawnandlandscape.com/fileuploads/ file/2016/11/SOI_PDF_2016.pdf $>$.

Mathers, H.M., A.A. Acuňa, D.R. Long, B.K. Behe, A.W. Hodges, J.J. Haydu, U.K. Schuch, S.S. Barton, J.H. Dennis, B.K. Maynard, C.R. Hall, R. McNiel, and T. Archer. 2010. Nursery worker turnover and language proficiency. HortScience 45:1-7.

Nielsen. 2013. The paid social media advertising report. 25 Aug. 2016. <http:// www.nielsen.com/us/en/insights / reports $/ 2013 /$ the-paid-social-mediaadvertising-report-2013.html>.

Sporleder, T.L. 1992. Managerial economics of vertically coordinated agricultural firms. Amer. J. Agr. Econ. 74:1226-1231. 